\title{
Addition of animal and microbial lipases to curd. Effects on free fatty acid composition during ripening
}

\author{
M De Felice 1, T Gomes 2, T De Leonardis 2 \\ ${ }^{1}$ Dipartimento di Scienze e Tecnologie Agro-Alimentari e Microbiologiche, Università degli Studi del \\ Molise, Via Tiberio 21/a, 86100 Campobasso; \\ 2 Istituto di Industrie Agrarie, Università degli Studi, via G Amendola 165/a 70126 Bari, Italy
}

(Received 2 January 1991; accepted 19 August 1991)

\begin{abstract}
Summary - Cheese-making tests were conducted in the laboratory, using animal (kid, lamb, calf) and microbial lipases, present in various commercial formulations, to aid in the development of flavour. The hydrolytic action of these lipases toward glycerides led to the liberation of substantial amounts of fatty acids whose composition showed distinct differences depending on the origin of the lipases that were utilized. Those of animal origin tended to liberate short chain fatty acids, mainly $\mathrm{C}_{4: 0}$ and $\mathrm{C}_{6: 0}$, while those of microbial origin did not show any preference for low or high molecular weight fatty acids so that the composition of free fatty acids was almost the same as that of untreated samples. The different behaviour of these adjuvants in the development of the aroma allows various lipase selections to be made according to the intensity of the "sharp" flavour desired in the marketable product.
\end{abstract}

lipase / curd / fatty acid compostion

Résumé - Addition de lipases d'origine animale et microbienne au caillé. Effets sur la composition en acides gras libres au cours de la maturation. On a mené des essais de fabrication de fromage au laboratoire, en utilisant comme additifs pour la formation du goût "piquant", des lipases d'origine animale (chevreau, agneau, veau) et d'origine microbienne (Mucor miehei, Aspergillus niger) sous forme de préparations commerciales diverses. L'action hydrolytique considérable sur les glycérides a mené à la libération de grandes quantités d'acides gras libres dont la composition présente des différences nettes suivant l'origine des enzymes utilisées. Les lipases d'origine animale libèrent préférentiellement des acides gras volatils, surtout $C_{4: 0}$ et $C_{6: 0}$, tandis que celles d'origine microbienne ne manifestent aucune préférence, ni pour les acides à faible poids moléculaire ni pour ceux à haut poids moléculaire, tant il est vrai que la composition des acides gras libres est presque égale à celle observée dans l'échantillon non traité. La différence de comportement de ces additifs sur la formation de l'arôme, permet de faire des choix selon l'intensité du goût "piquant" que l'on veut réaliser dans le produit à commercialiser.

lipase / caillé / composition des acides gras 


\section{INTRODUCTION}

Free fatty acids (FFA) exert a considerable influence on the organoleptic characteristics of some aged cheeses; indeed, they play a major role in the development of "sharp" flavour (Nelson et al, 1977; Cerning et al, 1984; Thibault, 1984).

It is also known that in these cheeses the hydrolysis of the glycerides is brought about by the lipases elaborated by the microbial flora of milk (Anderson, 1983; Chilliard and Lamberet, 1984) and cheese (Desnouveaux et al, 1986), as well as by the lipase present in rennet, especially in rennet paste (Catalano et al, 1985).

Studies were conducted to assess the efficacy of the use of coagulating proteases with the addition of lipase instead of rennet paste (Law and Wigmore, 1985).

Massoni et al (1983) utilized microbial lipase and obtained results that were significant, though inferior to those achieved with rennet paste.

Galante (1988) reported on the availability of a "lipase with a high specificity" (extracted from a particular strain of Aspergillus orizae) towards triglycerides (TG) containing medium chain fatty acids (FA) with results similar to those encountered in naturally ripened Cheddar cheese.

Previous research conducted by Long and Harper (1956) and Harper (1957) on Provolone and Romano cheese treated with crude enzyme preparations showed that the amount of $\mathrm{C}_{4: 0}$ liberated during ripening was directly related to the type of enzyme used.

As the technique used for the determination of FFA was silica gel column chromatography and as the enzyme preparations used were quite impure, the authors, could only suppose the occurrence of some selectivity in the liberation of FA, thus suggesting an adequate selection of lipases in the preparation of the Italian cheese considered.

Subsequently it has been elucidated that goat, kid, calf and lamb pregastric esterase exhibit a unique specificity for short chain fatty acids and preferentially hydrolyze the primary ester position of glycerine (Nelson et al, 1977).

Based on these studies, our aim was to further investigate the action of animal and microbial lipases, available in standardized form, for the liberation of FFA from triglycerides during curd ripening, making use of the latest and more accurate analytical techniques capable of detecting even small differences in behaviour.

\section{MATERIALS AND METHODS}

Samples derived from the same curd obtained by coagulation with purified rennin were taken into account. The curd had already been subjected to partial syneresis and showed the following features: $\mathrm{pH}=6.2$, moisture $=56.0 \%$.

Lipases from different sources supplied by various firms were added to the curd samples (table I).

Tests were conducted on curd samples of $250 \mathrm{~g}$; equivalent amounts of lipase (from 100$300 \mathrm{mg} / \mathrm{kg}$, corresponding to $30-100 \mathrm{LU}$ ) were added.

After the samples had been prepared and put into moulds they were maintained at $18-20^{\circ} \mathrm{C}$.

Ten and 20 days later, each sample was utilized to assess the amount of volatile free fatty acids (VFFA) and total free fatty acids (TFFA).

TFFA were recovered by liquid-liquid extraction by dispersing the cheese in a $10 \% \mathrm{H}_{2} \mathrm{SO}_{4}$ water solution. The solvent used was diethyl ether:petroleum ether $b p=40-60^{\circ} \mathrm{C}(1: 1, v: v)$.

The ether extract, with an ethanol-water solution $(4: 1, v: v)$ added, was brought to $\mathrm{pH}=10.0$ by $\mathrm{NaOH}$ solution; soaps, once separated and concentrated, were methylated directly in a glass flask with $6 \%$ anhydrous $\mathrm{HCl}$ in methanol and submitted to GLC analysis. 
Table I. Lipases utilized in test.

Lipases utilisées dans les essais.

\begin{tabular}{|c|c|c|c|c|}
\hline No & Source & Commercial name & Producer & \\
\hline 1 & Kid & Kid lipase & Miles & (USA) \\
\hline 2 & Kid & Capalase K & Dairyland Food & (USA) \\
\hline 3 & Kid & Kid lipase & Caglio Hansen & (Italy) \\
\hline 4 & Lamb & Capalase L & Dairyland Food & (USA) \\
\hline 5 & Lamb & Lamb lipase & Caglio Hansen & (Italy) \\
\hline 6 & Calf & Italase C & Dairyland Food & (USA) \\
\hline 7 & Calf & Lipase of calf & Caglio Hansen & (Italy) \\
\hline 8 & Lamb + kid & Capalase $\mathrm{KL}$ & Dairyland Food & (USA) \\
\hline 9 & Aspergillus niger & Palatase A & Novo Enzimi & (Italy) \\
\hline 10 & Mucor miehei & Novozym SP 283 & Novo Enzimi & (Italy) \\
\hline 11 & Mucor miehei & Piccantase A & Gist Brocades & (Holland) \\
\hline
\end{tabular}

VFFA were extracted by steam distillation from a dispersion of cheese in distilled water, brought to $\mathrm{pH}=4.0$ with diluted $\mathrm{H}_{2} \mathrm{SO}_{4}$.

The distilled product treated with $\mathrm{NaOH}$ solution up to $\mathrm{pH}=10.0$, reduced to a small volume by a water bath at a controlled temperature, was acidified with $\mathrm{H}_{3} \mathrm{PO}_{4}$ to liberate the $F A$ from the corresponding soaps: the FA were then submitted to GLC analysis.

The analysis of TFFA was carried out using a capillary gas chromatograph (Carlo Erba 5300 , Italy). A Supelcowax-10 fused silica capillary column $\mathrm{I}=30 \mathrm{~m}, \varnothing=0.32 \mathrm{~mm}$, film thickness $0.5 \mu \mathrm{m}$ (Supelchem, Milan, Italy) was used. The column was programmed from $60^{\circ} \mathrm{C}(2 \mathrm{~min})$ to $100^{\circ} \mathrm{C}$ at $45^{\circ} \mathrm{C} / \mathrm{min}$, then raised to $230^{\circ} \mathrm{C}$ at $5^{\circ} \mathrm{C} / \mathrm{min}$ and held at this temperature for 25 min. The carrier gas was $\mathrm{He}$, with an average linear velocity of $25 \mathrm{~cm} / \mathrm{s}$; the injector was on column with secondary cooling; the flame ionization detector temperature was $250^{\circ} \mathrm{C}$; methylundecanoate was used as internal standard.

The GLC analysis of VFFA was conducted using a gas chromatograph (Carlo Erba 4200, Italy), equipped with a glass column I $=1.8 \mathrm{~m}$, $\emptyset=4.0 \mathrm{~mm}$ packed with GP $10 \% \mathrm{SP}-1000 / 1 \%$ $\mathrm{H}_{3} \mathrm{PO}_{4}$ on WAW chromosorb $100 / 120$ mesh, oven temperature $155^{\circ} \mathrm{C}$, injector port and detector (FID) temperature $195^{\circ} \mathrm{C}, \mathrm{He}$ as carrier gas with a flow-rate of $56 \mathrm{ml} / \mathrm{min}$, and cyclopropancarboxylic acid as internal standard (CPC).
The main FA response factors relating to the 2 above-mentioned methodologies were obtained using appropriate calibration mixtures (De Felice et al, 1989).

\section{RESULTS AND DISCUSSION}

The results obtained are reported in tables II and III and refer to 10 and 20 days after beginning the tests.

It should be pointed out that for the individual $F A$, values for $C_{4: 0}$ and $C_{6: 0}$ were obtained from the GLC of VFFA while those for the other FA were derived from the GLC analysis of TFFA.

Moreover, it is known that acetic acid is normally present in VFFA: in the analyzed samples, this component ranged from 23 to $60 \%$. It was not thought suitable to report it among the constituents of acidic composition in spite of such high quantities, as this acid is not a product of lipolysis.

The action of lipases on glyceride hydrolysis in all the treated samples considering not only TFFA but also VFFA ap- 
Table II. Curd with lipase added * $: 10$ days after beginning the test. Caillé avec addition de lipase * 10 jours après le début de l'essai.

\begin{tabular}{|c|c|c|c|c|c|c|c|c|c|c|c|c|c|c|}
\hline \multirow[t]{2}{*}{ Samples } & \multirow{2}{*}{$\begin{array}{l}\text { TFFA } \\
\mathrm{mg} / \mathrm{kg}\end{array}$} & \multirow{2}{*}{$\begin{array}{l}V F F A \\
m g / k g\end{array}$} & \multirow{2}{*}{ C4:0 } & \multirow{2}{*}{ c6:0 } & \multicolumn{6}{|c|}{ Composition of TFFA mg/kg } & \multirow[b]{2}{*}{ C18:0 } & \multirow[b]{2}{*}{ C18:1 } & \multirow[b]{2}{*}{ C18:2 } & \multirow[b]{2}{*}{ Others } \\
\hline & & & & & C8:0 & C10:0 & C12:0 & C14:0 & C16:0 & C16:1 & & & & \\
\hline $\begin{array}{l}\text { Control } \\
\text { ( } 0 \text { days })\end{array}$ & 1220 & 425 & 135 & 70 & 27 & 52 & 63 & 162 & 422 & 16 & 67 & 262 & 32 & 56 \\
\hline 0 & 3250 & 1225 & 232 & 105 & 55 & 130 & 146 & 429 & 1232 & 36 & 192 & 676 & 97 & 83 \\
\hline $1^{*}$ & 4520 & 1970 & 500 & 205 & 92 & 240 & 267 & 749 & 1505 & 59 & 217 & 683 & 154 & 90 \\
\hline $2^{*}$ & 5470 & 2275 & 965 & 450 & 137 & 284 & 290 & 764 & 1734 & 44 & 235 & 941 & 159 & 107 \\
\hline $3^{*}$ & 5880 & 1865 & 772 & 227 & 165 & 288 & 329 & 794 & 1846 & 59 & 294 & 1105 & 165 & 70 \\
\hline 4 * & 6230 & 2305 & 984 & 348 & 116 & 270 & 313 & 800 & 2004 & 31 & 323 & 1128 & 182 & 120 \\
\hline $5^{*}$ & 6900 & 2215 & 988 & 425 & 179 & 366 & 372 & 849 & 2125 & 62 & 359 & 1235 & 179 & 92 \\
\hline 6 * & 5480 & 1830 & 690 & 226 & 120 & 274 & 318 & 674 & 1644 & 44 & 285 & 986 & 170 & 190 \\
\hline 7 * & 6080 & 2210 & 894 & 403 & 167 & 341 & 347 & 753 & 1820 & 48 & 263 & 1100 & 173 & 103 \\
\hline 8 * & 5150 & 2225 & 813 & 351 & 93 & 206 & 232 & 700 & 1668 & 31 & 247 & 920 & 149 & 100 \\
\hline 9 * & 4750 & 1150 & 243 & 121 & 90 & 214 & 256 & 674 & 1724 & 24 & 303 & 959 & 166 & 83 \\
\hline $10^{*}$ & 9150 & 1420 & 396 & 209 & 165 & 352 & 338 & 1216 & 3422 & 110 & 631 & 1967 & 247 & 153 \\
\hline 11 * & 8130 & 2135 & 418 & 233 & 122 & 382 & 423 & 1114 & 3130 & 89 & 520 & 1658 & 211 & 63 \\
\hline
\end{tabular}

* Lipase from: 1, 2, 3 = kid; 4, 5 = lamb; 6, 7 = calf; 8 = kid + lamb; 9 = Aspergillus niger ; 10, 11 = Mucor miehei. ** Determined on VFFA. 
Table III. Curd added with lipase * $: 20$ days after beginning the test.

Caillé avec addition de lipase " : 20 jours après le début de l'essai.

\begin{tabular}{|c|c|c|c|c|c|c|c|c|c|c|c|c|c|c|}
\hline \multirow[t]{2}{*}{ Samples } & \multirow{2}{*}{$\begin{array}{l}\text { TFFA } \\
m g / k g\end{array}$} & \multirow{2}{*}{$\begin{array}{l}V F F A \\
m g / k g\end{array}$} & \multirow{2}{*}{$\begin{array}{l}* * \\
C 4: 0\end{array}$} & \multirow{2}{*}{$\begin{array}{l}* * \\
66: 0\end{array}$} & \multicolumn{5}{|c|}{ Composition of TFFA mg/kg } & \multirow[b]{2}{*}{ C16:1 } & \multirow[b]{2}{*}{ C18:0 } & \multirow[b]{2}{*}{ C18:1 } & \multirow[b]{2}{*}{ C18:2 } & \multirow[b]{2}{*}{ Others } \\
\hline & & & & & C8:0 & C10:0 & C12:0 & C14:0 & C16:0 & & & & & \\
\hline $\begin{array}{l}\text { Control } \\
\text { (0 days) }\end{array}$ & 1220 & 425 & 135 & 70 & 27 & 57 & 63 & 162 & 422 & 16 & 67 & 262 & 32 & 56 \\
\hline 0 & 4400 & 1810 & 338 & 132 & 79 & 185 & 216 & 594 & 1544 & 57 & 252 & 915 & 132 & 129 \\
\hline 1 * & 4790 & 1770 & 450 & 188 & 129 & 259 & 273 & 661 & 1475 & 48 & 206 & 805 & 144 & 199 \\
\hline $2^{*}$ & 7560 & 3405 & 1481 & 742 & 203 & 377 & 370 & 907 & 2091 & 44 & 319 & 1256 & 203 & 125 \\
\hline 3 * & 7970 & 3810 & 1516 & 434 & 223 & 422 & 422 & 1004 & 2230 & 80 & 303 & 1250 & 223 & 150 \\
\hline $4^{*}$ & 9470 & 3890 & 1657 & 572 & 237 & 501 & 520 & 1181 & 2589 & 104 & 405 & 1491 & 242 & 188 \\
\hline 5 * & 9870 & 4175 & 1778 & 789 & 266 & 523 & 474 & 1242 & 2650 & 108 & 434 & 1617 & 276 & 116 \\
\hline $6^{*}$ & 8040 & 2990 & 1097 & 323 & 212 & 399 & 440 & 1050 & 2377 & 57 & 407 & 1343 & 236 & 226 \\
\hline $7^{*}$ & 7960 & 3160 & 1428 & 464 & 223 & 382 & 430 & 1108 & 2331 & 80 & 310 & 1211 & 231 & 133 \\
\hline 8 * & 9870 & 3425 & 1551 & 503 & 276 & 513 & 513 & 1204 & 2993 & 109 & 434 & 1580 & 237 & 144 \\
\hline 9 * & 9470 & 1870 & 402 & 163 & 208 & 407 & 445 & 1288 & 3489 & 114 & 483 & 1865 & 275 & 445 \\
\hline $10^{*}$ & 16430 & 2630 & 723 & 352 & 394 & 706 & 756 & 2090 & 6037 & 181 & 996 & 2990 & 444 & 906 \\
\hline 11 * & 12610 & 2590 & 720 & 326 & 239 & 504 & 517 & 1665 & 4942 & 139 & 794 & 2508 & 328 & 193 \\
\hline
\end{tabular}

${ }^{*}$ Lipase from: 1, 2, 3 = kid; 4, 5 = lamb; $6,7=$ calf; $8=$ kid + lamb; $9=$ Aspergillus niger, 10, $11=$ Mucor miehei. ${ }^{*}$ Determined on VFFA. 
pears evident. In fact, 10 days after beginning the tests, values of $4500-9000 \mathrm{mg} /$ $\mathrm{kg}$ TFFA and $1100-2300 \mathrm{mg} / \mathrm{kg}$ VFFA were recorded, while 20 days thereafter the values were $5000-16000 \mathrm{mg} / \mathrm{kg}$ for the former and $1800-4200 \mathrm{mg} / \mathrm{kg}$ for the latter.

The control curd presented amounts of TFFA and VFFA corresponding to 3200 and $1200 \mathrm{mg} / \mathrm{kg}$ respectively after 10 days and 4400 and $1800 \mathrm{mg} / \mathrm{kg}$ after 20 days.

An exception was sample No 9 which on the TFFA basis presented at 10 and 20 days quantities of low molecular weight acids identical to those in the control sample despite the accentuated lipolysis. The data obtained relative to VFFA and TFFA ranged between the minimum and maximum values usually observed in Provolone cheeses with different degrees of ripening (De Felice et al, 1989).

The FFA composition makes it possible to assess the type of preference expressed by the lipases from various sources in the liberation of FA from triglycerides. In order to make the differences more evident, a meaningful ratio of free $\mathrm{C}_{4: 0}+\mathrm{C}_{6: 0}$ to free $\mathrm{C}_{14: 0}+\mathrm{C}_{16: 0}$ was calculated.

In figure 1, the value of the ratio demontrates that there are distinct differences in the selectivity of the various lipases. In any case, the significance of these ratios is similar at 10 as well as at 20 days after beginning the tests.

Whatever the commercial formulation and the producer firm, the lipase from kid and that from lamb show a clear lipolytic preference for low molecular weight fatty acids, especially $\mathrm{C}_{4: 0}$ and $\mathrm{C}_{6: 0}$. Also, the lipase from calf behaved in a similar manner by liberating low molecular weight acids independently of the commercial formulations.
The behaviour of the 2 microbial lipases is similar in relation to both the species of the producer organism and the commercial formulations examined.

These lipases, however, exert hydrolytic actions that are distinctly different from the lipases from animal sources. In fact, although lipolysis is much more intense than that in the control, the composition of liberated fatty acids and the ratio between free $\mathrm{C}_{4: 0}+\mathrm{C}_{6: 0}$ and free $\mathrm{C}_{14: 0}+\mathrm{C}_{16: 0}$ almost coincide with those of the control sample.

This behaviour, clearly different from that of the lipases from animal sources, makes it possible to achieve a guided hydrolysis of the glycerides in cheeses with the formation of different quantities of individual FFA.

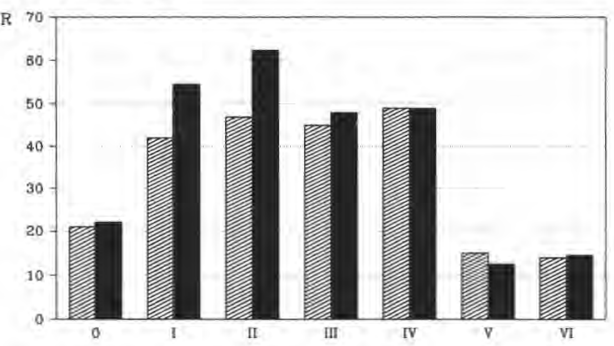

Fig 1. Curd samples with the addition of lipase : I) kid; II) lamb, III) calf; IV) kid + lamb; V) Aspergillus niger, VI) Mucor miehei; 0) control curd; $10 \mathbb{N a n d} 20$ lays after the beginning of the experiment. Mean values of ratios of fatty acids resulting from the addition of lipase :

$$
R=\frac{\left(\mathrm{C}_{4: 0}+\mathrm{C}_{6: 0}\right) \times 100}{\left(\mathrm{C}_{14: 0}+\mathrm{C}_{16: 0}\right)}
$$

Échantillons de caillé avec addition de lipase : I) chevreau; II) agneau; III) veau; IV) chevreau + agneau; V) Aspergillus niger; VI) Mucor miehei;

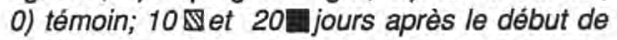
l'expérience. Valeurs moyennes des rapports des acides gras résultant de l'addition de la lipase:

$$
\mathrm{R}=\frac{\left(C_{4: 0}+C_{6: 0}\right) \times 100}{\left(C_{14: 0}+C_{16: 0}\right)}
$$




\section{CONCLUSIONS}

The distinctly different behaviour of the lipases from microbial sources compared with those of animal origin with regard to more or less selectivity in the liberation of high and low molecular weight FA, offers the possibility of making specific choices. In fact, when such adjuvants are utilized in the preparation for the ripening of typical cheeses, it is possible to produce degrees of sharpness varying from a more or less distinct sharpness to just a hint of it. In the case of the former, the use of animal lipases makes it possible to reach the desired degree of sharpness in a shorter time than in the case of traditional cheese. On the other hand, use of microbial lipases (elaborated and extracted from Mucor miehei and from Aspergillus niger), though leading to a rise in the rate of hydrolysis, yields products with a limited amount of VFFA and a milder aroma, since the relative composition of free acids appears to be almost the same as that of the untreated sample.

\section{REFERENCES}

Anderson M (1983) Milk lipase and off-flavour development. J Soc Dairy Technol 36, 3-7

Catalano M, De Felice M, Gomes T (1985) Influenza della frazione lipidica sulla qualità dei formaggi. Latte 10, 936-943
Cerning J, Gripon JP, Desmazeaud MJ (1984) Utilisation des enzymes dans l'industrie laitière. Tech Lait 992, 9-24

Chilliard Y, Lamberet G (1984) La lipolyse dans le lait : les différents types, mécanismes, facteurs de variations, signification pratique. Lait 64, 544-578

De Felice M, Gomes T, De Leonardis T (1989) I prodotti della idrolisi enzimatica dei gliceridi nel formaggio Provolone. Nota I. Ind Latte $25,27-45$

Desnouveaux R, Driou A, Linden G (1986) Point actuel sur le rôle des enzymes dans la maturation et l'affinage des fromages. Ind Aliment Agric 103, 305-315

Galante YM (1988) Nuovi biocatalizzatori enzimatici. Ind Latte 24, 73-78

Harper WJ (1957) Lipase systems used in the manufacture of Italian cheese. II. Selective hydrolysis. J Dairy Sci 40, 556-563

Law BA, Wigmore A (1985) Effect of commercial lipolytic enzymes on flavour development in Cheddar cheese. J Soc Dairy Technol 38, 86-88

Long JE, Harper WJ (1956) Italian cheese ripening. VI. Effects of different types of lipolytic enzyme preparation on the accumulation of various free fatty and free amino acids and the development of flavor in Provolone and Romano cheese. J Dairy Sci 39, 245-252

Massoni F, Dallavalle MG, Lodi R (1983) Impiego di coagulante e lipasi di origine microbica nella produzione di Provolone. Ind Latte 19, 3-16

Nelson JH, Jensen RG, Pitas RE (1977) Pregastric esterase and other oral lipases. A review. $J$ Dairy Sci 60, 327-362

Thibault P (1984) Les enzymes dans l'industrie laitière. Tech Lait 27, 35-39 